\title{
sciendo

\section{Multi-Criteria Analysis to Select Renewable Energy Solution for District Heating System}

\author{
Ilze POLIKARPOVA ${ }^{1 *}$, Dace LAUKA ${ }^{2}$, Dagnija BLUMBERGA ${ }^{3}$, Edgars VIGANTS ${ }^{4}$ \\ ${ }^{1-4}$ Institute of Energy Systems and Environment, Riga Technical University, \\ Azenes iela 12/1, Riga, LV-1048, Latvia
}

\begin{abstract}
The research paper is focused on how to choose the most suitable renewable energy solution using multi-criteria analysis for a district heating system. Making choices is based on indicators - economic, environmental and social. In this case, the study used five indicators: resources costs, totals investments, reduction of greenhouse gas emissions, specific weight of renewable energy resources and impact on utilized land. Three situations have been compared - current situation: gas boiler, planned: solar collectors $21595 \mathbf{m}^{2}+$ accumulation tank $8000 \mathrm{~m}^{3}$ and alternatives: solar PV panels $5504 \mathrm{~m}^{2}$ - heat pump COP 3 are used in the estimation. The multi-criteria decision-making analysis shows that solar collectors $21595 \mathbf{~ m}^{2}$ + accumulation tank $8000 \mathrm{~m}^{3}$ are considered as the best alternative. The methodology is based on choosing a solution for a district heating company in Latvia.
\end{abstract}

Keywords - Accumulation tank; alternatives; district heating; multi-criteria analysis; renewable energy; solar collectors; TOPSIS

\section{INTRODUCTION}

District heating systems are beginning to change, going from $3^{\text {rd }}$ generation heat sources to $4^{\text {th }}$ generation heat sources. One of the most important aspects of this transition is integration of renewable energy sources (hereinafter RES). The main aim is to achieve a non-fossil district heat supply system, which will be a sustainable energy system [1]. Energy and climate policy is based on increasing renewable energy resources to reduce greenhouse gas emissions. To increase renewable energy sources to $54 \%$ by 2030 in district heating in Latvia, is part of the objective in Latvia's National Energy and Climate Plan 2021-2030 [2].

To achieve the target, a large part of the responsibility is placed on medium and large heat producers. According to Regulation No. 736 of the Cabinet of Ministers, the average combustion plant is $\geq 1 \mathrm{MW} \leq 50$. A large-scale heat producer is above $50 \mathrm{MW}$. The Regulation determines that from December 2018, all new boiler houses must comply with the stringent environmental requirements, and already installed boilers must comply to these same requirements from 2025.

Therefore, it would be far-sighted to replace incineration plants with 4 generations of equipment using solar, wind and recovered heat.

In Latvia there are 631 boiler houses and 175 combined heat and power plants (hereinafter CHP) which in total produced 7.15 TWh heat in 2017 according to central statistics data [3]. Every year Latvia's district heating companies develop and reduce fossil fuel use. Using EU

\footnotetext{
* Corresponding author.

E-mail address: ilze.polikarpova@ gmail.com

C2019 Ilze Polikarpova, Dace Lauka, Dagnija Blumberga, Edgars Vigants.

This is an open access article licensed under the Creative Commons Attribution License (http://creativecommons.org/ licenses/by/4.0), in the manner agreed with Sciendo.
} 
funds 106 projects will be implemented to increase efficiency in heat sources, heat networks and move to renewable energy by 2020 [4].

In district heating systems (DHS), the most often used renewable energy sources (RES) include biomass [5], [6], wind [8], geothermal [7] and solar. In the last years, thermal solar energy [8] is used more and more in DHS. The largest thermal solar energy plants are in Denmark [10], and Latvia and Denmark have similar climate conditions.

In order to choose the most appropriate solution, there is need to conduct analyses of multiple criteria: economic, environmental and social. Multiple Criteria Decision Making (hereinafter MCDM) methods generally require the decision maker to evaluate alternatives with respect to decision criteria and also to assign importance weights to the criteria [11]-[13].

This research study is focusing on selecting the best RES energy technology solution to medium, local district heating systems in Latvia using the multi-criteria decision analysis method: TOPSIS. The TOPSIS and principle of TOPSIS (Technique for order performance by similarity to ideal solution) method is presented by Chen and Hwang.

\section{Methodology OF ReSEARCH}

In this case study, the methodology is applied to an average district heating company with an installed capacity of about $30 \mathrm{MW}$. In the current system, $60 \%$ of renewable energy is from renewable energy sources, $40 \%$ from fossil fuel - natural gas. One goal is to increase energy independency and reduce fossil fuel use by up to $10 \%$.

\section{TABLE 1. TECHNOLOGY DISTRIBUTION BY LOAD}

\begin{tabular}{|c|c|c|c|c|c|c|}
\hline \multirow[b]{2}{*}{$\begin{array}{l}\text { Summer } \\
\text { load }\end{array}$} & \multicolumn{2}{|c|}{ Current situation } & \multirow{2}{*}{\multicolumn{2}{|c|}{$\begin{array}{l}\text { Planned situation } \\
\text { Solar collectors } 21595 \mathrm{~m}^{2}+ \\
\text { accumulation tank } 8000 \mathrm{~m}^{3}\end{array}$}} & \multirow{2}{*}{\multicolumn{2}{|c|}{$\begin{array}{l}\text { Alternative situation } \\
\text { Solar PV panels } 5504 \mathrm{~m}^{2} \\
\text { - heat pump COP } 3\end{array}$}} \\
\hline & $3 \mathrm{MW}$ & $\begin{array}{l}\text { Condensing gas } \\
\text { boiler }\end{array}$ & & & & \\
\hline Base load & $\begin{array}{l}7 \mathrm{MW}+ \\
1.68 \mathrm{MW}\end{array}$ & $\begin{array}{l}\text { Woodchip boiler } \\
\text { + flue gas } \\
\text { condenser }\end{array}$ & $\begin{array}{l}7 \mathrm{MW}+ \\
1.68 \mathrm{MW}\end{array}$ & $\begin{array}{l}\text { Woodchip boiler + } \\
\text { flue gas condenser }\end{array}$ & $\begin{array}{l}7 \mathrm{MW}+ \\
1.68 \mathrm{MW}\end{array}$ & $\begin{array}{l}\text { Woodchip } \\
\text { boiler }+ \\
\text { flue gas } \\
\text { condenser }\end{array}$ \\
\hline $\begin{array}{l}\text { Above the } \\
\text { base load }\end{array}$ & $3 \mathrm{MW}$ & $\begin{array}{l}\text { Same condensing } \\
\text { gas boiler }\end{array}$ & $\begin{array}{l}3 \mathrm{MW}+ \\
0.5 \mathrm{MW}\end{array}$ & $\begin{array}{l}\text { Woodchip boiler + } \\
\text { flue gas condenser }\end{array}$ & $3 \mathrm{MW}$ & $\begin{array}{l}\text { Woodchip } \\
\text { boiler }+ \\
\text { flue gas } \\
\text { condenser }\end{array}$ \\
\hline Peak load & $2 \cdot 10 \mathrm{MW}$ & Gas boiler & $2 \cdot 10 \mathrm{MW}$ & Gas boiler & $2 \cdot 10 \mathrm{MW}$ & Gas boiler \\
\hline
\end{tabular}

Multi-criteria analysis will select variations to the summer load - solar collector system with accumulation tank in planned version and alternative heat pump and solar cells.

The developed framework for choosing suitable RES technology for a district heating company is illustrated in Fig. 1.

To make the right decision one needs to choose an indicator that objectively characterizes the situation. The first step to use MCDM is to select criteria. Criteria can be classified into four aspects: technical, economic, environmental and social [14]. In literature and in the heat sector can find many different indicators that are used to compare technologies (see Fig. 2) [15], [16]. First those most used are collected, and after five heat industry specialists choose the most important ones. During the process of identifying the most valuable indicator, it was scaled to the particular situation. In this case study, the two most important aspects are economic and environmental due to the fact that the economic aspect has a direct impact on 
the heat tariff, and the company's goal is to deliver heat safely and at the lowest possible price. The environmental aspect is also very important, as the heat demand increase every year. For companies operating in the energy sector that are in the ETS system in the $4^{\text {th }}$ period from 2020 to $2030, \mathrm{CO}_{2}$ allowances will no longer be granted. During the transitional period, $30 \%$ of the previous period will be calculated for companies that have previously had free allowances [17]. It is therefore important to move to renewable energy in time.

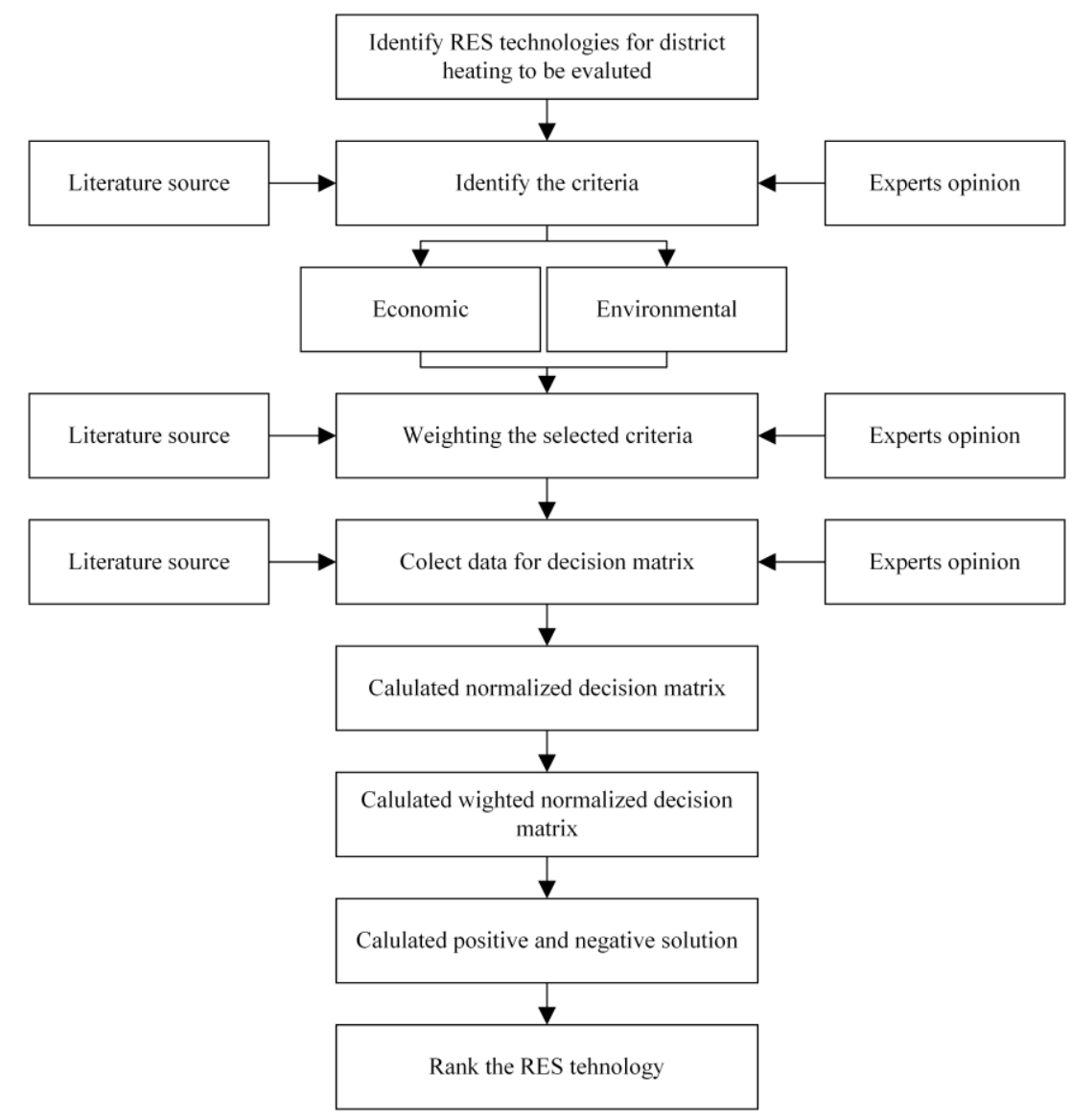

Fig. 1. Decision-making framework.

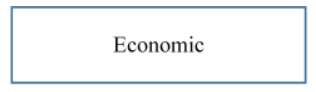

Total investments

Payback period

Subsidy

Resource costs
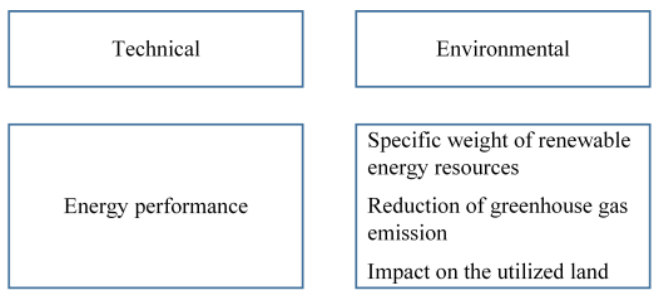

Specific weight of renewable energy resources

Reduction of greenhouse gas emission

Impact on the utilized land
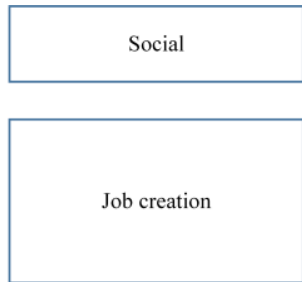

Fig. 2. Indicators for Renewable Energy Heating Technologies. 
After summarizing indicators, TOPSIS is applied to make a decision. The procedure of TOPSIS consists of main five steps: normalized decision matrix, weighted normalized decision matrix, positive ideal and negative ideal solution, positive ideal and negative ideal solution and calculation of the relative closeness to the ideal solution.

The energy technology is evaluated with four criteria. The selected indicators are: total investments, resources costs, reduction of greenhouse gas emissions and impact on the utilized land. Experts selected the importance of the selected criteria from 0 to 5 by significance, 0 no influence -5 extremely high influence:

- No influence: 0;

- Extremely low influence: 1;

- Moderately low influence: 2;

- Medium influence: 3;

- Moderately high influence: 4;

- Extremely high influence: 5.

Summarizing ratings were calculated weights. All chosen criteria weight in sum is equal to 1. Criteria weights for chosen indicators are as fallow:

- Total investments (ET): 0.18;

- Reduction of greenhouse gas emissions (ERG): 0.23;

- Resource costs (ER): 0.25;

- Impact on the utilized land (EI): 0.14;

- Specific weight of renewable energy resources (ES): 0.2.

Step one, in accordance with TOPSIS, is to calculate the normalized decision matrix. The normalized value $r_{i j}$ is calculated as follows:

$$
r_{i j}=\frac{\max \alpha_{i j}-\alpha_{i j}}{\max \alpha_{i j}-\min \alpha_{i j}},
$$

if $\max a_{i j}$ is preferable;

$$
r_{i j}=\frac{\alpha_{i j}-\min \alpha_{i j}}{\max \alpha_{i j}-\min \alpha_{i j}},
$$

if $\min a_{i j}$ is preferable.

Calculate the weighted normalized decision matrix. The weighted normalized value $v_{i j}$ is calculated as follows:

$$
v_{i j}=r_{i j} \cdot w_{i}
$$

The next step determines the ideal $\mathrm{A}^{+}$and negative ideal $\mathrm{A}^{-}$solutions:

$$
\begin{aligned}
& A^{*}=\left\{\left(\max _{i} v_{i j} \mid j \in C_{b}\right),\left(\min _{i} v_{i j} \mid j \in C_{c}\right)\right\}=\left\{v_{j}^{*} \mid j=1,2, \ldots, m\right\}, \\
& A^{-}=\left\{\left(\min _{i} v_{i j} \mid j \in C_{b}\right),\left(\max _{i} v_{i j} \mid j \in C_{c}\right)\right\}=\left\{v_{j}^{-} \mid j=1,2, \ldots, m\right\} .
\end{aligned}
$$


Calculate the separation measures using the m-dimensional Euclidean distance. The separation measures of each alternative from the positive ideal solution and the negative ideal solution, respectively, are as follows:

$$
S^{+}=\sqrt{\sum_{j=1}^{n}\left(v_{i j}-v_{j}^{+}\right)^{2}}
$$

where $i=1,2, \ldots, m$.

$$
S^{-}=\sqrt{\sum_{j=1}^{n}\left(v_{i j}-v_{j}^{-}\right)^{2}}
$$

The final step is to calculate the relative closeness to the ideal solution. The relative closeness of the alternative with respect to $\mathrm{A}^{+}$is defined as follows:

$$
C_{i}^{*}=\frac{S_{i}^{-}}{\left(S_{i}^{+}+S_{i}^{-}\right)},
$$

if $C_{i}^{*}=1$, alternative is the ideal solution and if $C_{i}^{*}=0$, alternative is the Negative-Ideal solution.

\section{RESUlts}

In the original decision-making matrix in Table 3, all five indicators to all three scenarios are presented. The data in terms of current situation and planned situation are taken and calculated from company data. Data to alternative situation are taken from offers from companies. Resources cost to natural gas is average to medium district heating company per EUR to MWh, in Latvia natural gas price is split into two parts: consumption and distribution. In terms of the planned situation, alternative costs are considered to be 0 , because the energy resource is the sun. Only in the actual situation are greenhouse gases emitted. In the actual situation in $2018,50 \%$ heat was produced using natural gas, second $50 \%$ of heat is produced using renewable energy resources - from the woodchip boiler and from the flue gas condenser. In both alternatives, it is planned to refuse from the use of fossil fuels, and use them only at peak loads (see in Table 1). Both newer alternatives require extra land. In the planned situation is necessary to prepare 6.5 ha of land to install solar collectors with $21595 \mathrm{~m}^{2}$ active square. An alternative to the solution is about the same area, but below it must be installed the active surface of the ground heat pump. The total investment is attributed to the unit of installed MW. In the current situation, no investments is 0 , because all the equipment is already present at the plant. Both alternatives are designed to cover the summer load, with an average power of up to $3 \mathrm{MW}$. The planned system has a capacity of $12.3 \mathrm{MW}$, but has an $8000 \mathrm{~m}^{3}$ accumulation tank, which accumulates heat for the period when there is no solar energy. But for the alternative, the installed capacity of the heat pump is $3 \mathrm{MW}$ of heat produced. Since the energy source of the heat pump is from PV panels, during the night mode, electricity should be taken from the grid. 
TABLE 4. ORIGINAL DECISION MAKING MATRIX

\begin{tabular}{|c|c|c|c|c|c|}
\hline & Resource costs & $\begin{array}{l}\text { Reduction of } \\
\text { greenhouse gas } \\
\text { emissions }\end{array}$ & $\begin{array}{l}\text { Specific weight } \\
\text { of renewable } \\
\text { energy resources }\end{array}$ & $\begin{array}{l}\text { Impact on } \\
\text { utilized land }\end{array}$ & $\begin{array}{l}\text { Total } \\
\text { investments }\end{array}$ \\
\hline $\begin{array}{l}\text { Current } \\
\text { situation }\end{array}$ & 35 & 0.48 & 50 & 0 & 0 \\
\hline $\begin{array}{l}\text { Planned } \\
\text { situation }\end{array}$ & 0 & 0 & 90 & 2 & 375000 \\
\hline \multirow[t]{2}{*}{$\begin{array}{l}\text { Alternative } \\
\text { situation }\end{array}$} & 0 & 0 & 90 & 3 & 613333 \\
\hline & $\min$ & $\min$ & $\max$ & $\min$ & $\min$ \\
\hline Weights & 0.25 & 0.23 & 0.2 & 0.14 & 0.18 \\
\hline
\end{tabular}

After normalizing the values, one obtains a matrix where values are from 0 to 1 , after which it is easier to compare results, see Table 5.

TABLE 5. NORMALIZED DECISION MATRIX

\begin{tabular}{llllll}
\hline & Resource costs & $\begin{array}{l}\text { Reduction of } \\
\text { greenhouse } \\
\text { gas } \\
\text { emissions }\end{array}$ & $\begin{array}{l}\text { Specific weight } \\
\text { of renewable } \\
\text { energy resources }\end{array}$ & $\begin{array}{l}\text { Impact on } \\
\text { utilized land }\end{array}$ & Total investments \\
\hline Current situation & 0.00 & 0.00 & 0.37 & 0.95 & 0.93 \\
Planned situation & 0.71 & 0.71 & 0.66 & 0.32 & 0.36 \\
Alternative situation & 0.71 & 0.71 & 0.66 & 0.00 & 0.00 \\
\hline
\end{tabular}

In TOPSIS an important part is indicator weight, which is determined by district heating experts. One criteria can be highly dominant, and can be equivalent. In this case study, all indicators, one can say, are equivalent. The most important indicator is resource cost, because the company gains more energy independence and changes in energy prices have less impact. The next important indicator is reduction of $\mathrm{CO}_{2}$ emissions. Reducing greenhouse gases is an important part of choosing renewable energy sources. To make a decision, there is a need to put weight via a normalized matrix (see Table 6).

\section{TABLE 6. Weighted NoRMALIZEd DeCISION MATRIX}

\begin{tabular}{llllll}
\hline & Resource costs & $\begin{array}{l}\text { Reduction of } \\
\text { greenhouse gas } \\
\text { emissions }\end{array}$ & $\begin{array}{l}\text { Specific weight } \\
\text { of renewable } \\
\text { energy resources }\end{array}$ & $\begin{array}{l}\text { Impact on } \\
\text { utilized land }\end{array}$ & $\begin{array}{l}\text { Total } \\
\text { investments }\end{array}$ \\
\hline $\begin{array}{l}\text { Current } \\
\text { situation }\end{array}$ & 0.000 & 0.000 & 0.073 & 0.133 & 0.168 \\
$\begin{array}{l}\text { Planned } \\
\text { situation }\end{array}$ & 0.177 & 0.163 & 0.132 & 0.044 & 0.065 \\
$\begin{array}{l}\text { Alternative } \\
\text { situation }\end{array}$ & 0.177 & 0.163 & 0.132 & 0.000 & 0.000 \\
\hline
\end{tabular}

The point calculated matrix identifies the ideal, where the ideal is 0 and the rest shows in terms of steps to the ideal. The lower the value; the closer to the ideal. The positive ideal solution for resource cost is in the planned and alternative situation, because the solar energy cost is 0 , but the current situation contains average natural gas prices. For reduction of 
greenhouse gas emissions and specific weight of renewable energy resources, the same options include resource costs. Impact on the utilized land and total investments ideal solution is current situation, because do not need new investments and no more impact to land. The results are summarized in Table 7 .

TABLE 7. POSITIVE IDEAL SOLUTION

\begin{tabular}{llllll}
\hline & Resource costs & $\begin{array}{l}\text { Reduction of } \\
\text { greenhouse gas } \\
\text { emissions }\end{array}$ & $\begin{array}{l}\text { Specific weight } \\
\text { of renewable } \\
\text { energy resources }\end{array}$ & $\begin{array}{l}\text { Impact on } \\
\text { utilized land }\end{array}$ & Total investments \\
\hline Current situation & 0.177 & 0.163 & 0.059 & 0.000 & 0.000 \\
Planned situation & 0.000 & 0.000 & 0.000 & 0.089 & 0.103 \\
Alternative situation & 0.000 & 0.000 & 0.000 & 0.133 & 0.168 \\
\hline
\end{tabular}

The reverse process to the find ideal solution is to find the negative solution. The negative solution is the opposite ideal to resource costs, reduction of greenhouse gas emissions and specific weight of renewable energy resources anti-idol solution is current situation. The results are summarized in Table 8 .

TABLE 8. NEGATIVE IDEAL SOLUTION

\begin{tabular}{llllll}
\hline & Resource costs & $\begin{array}{l}\text { Reduction of } \\
\text { greenhouse } \\
\text { gas emissions }\end{array}$ & $\begin{array}{l}\text { Specific weight } \\
\text { of renewable } \\
\text { energy resources }\end{array}$ & $\begin{array}{l}\text { Impact on } \\
\text { utilized land }\end{array}$ & Total investments \\
\hline Current situation & 0.000 & 0.000 & 0.000 & 0.133 & 0.168 \\
Planned situation & 0.177 & 0.163 & 0.059 & 0.044 & 0.065 \\
Alternative situation & 0.177 & 0.163 & 0.059 & 0.000 & 0.000 \\
\hline
\end{tabular}

The TOPSIS result of this case study, to choose the most suitable energy technology for medium district heating company, is presented in Table 9. Indicates that prior is planned alternative-solar collector with accumulation tank, second best is alternative heat pump with PV panels.

In this case study, the current situation was evaluated where nothing changes, in the summer a gas boiler is use and 2 alternative situations, where RES was used were considered. This study presents a multi-criteria decision making method to prioritize three situations.

TABLE 9. TOPSIS RESULT OF THE IDEAL/ANTI-IDOL POINTS AND THE ClosenESS COEFFICIENTS WITH RESPECT TO THE TREE SCENARIOS

\begin{tabular}{llll}
\hline $\mathrm{di}^{+}$ & $\mathrm{di}^{-}$ & $\mathrm{ci}$ & Result rank \\
\hline 0.25 & 0.21 & 0.46 & 3.00 \\
0.14 & 0.26 & 0.66 & 1.00 \\
0.21 & 0.25 & 0.54 & 2.00 \\
\hline
\end{tabular}

A total of five indicators for decision making cover economic and environmental aspects, however future studies should consider a wider range of aspects. The best option is the planned version where solar collectors and storage tanks will be installed (see Fig. 3). 


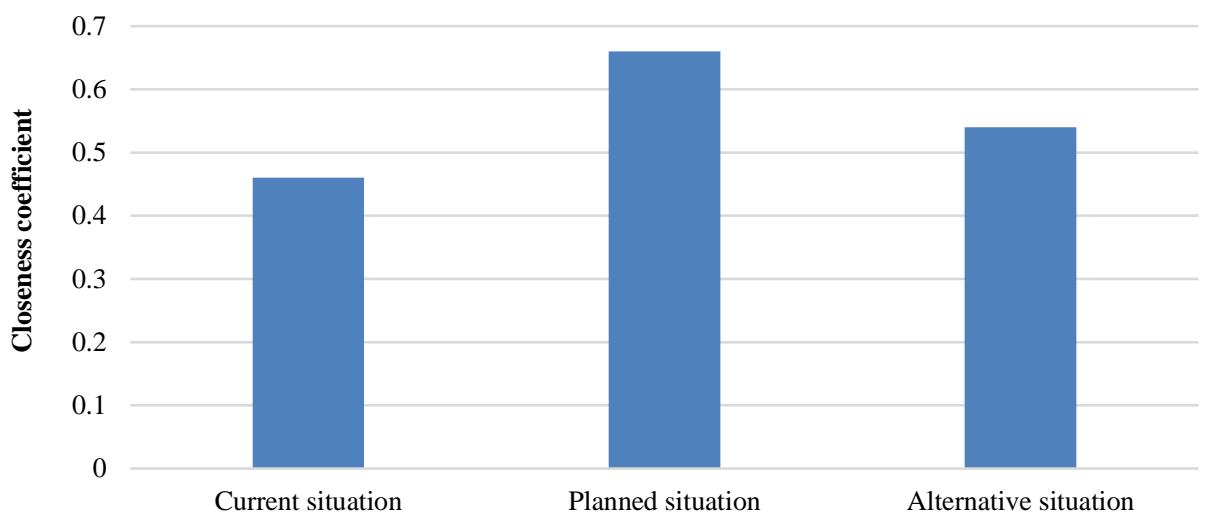

Fig. 3. The coefficients for 3 systems in case study.

\section{Conclusions}

After the multi-criteria analysis, the best option is the planned scenario where the solar collector field and the accumulation tank are installed. This alternative is better than heat pump with PV panels, because investment to installed MW is lower and impact to the land less. If the second alternative would be the accumulation tank and in there is no need to take electricity from the grid at night, then the result would be different. Because then, during the day you can produce more and accumulate heat that can be used at night. Although in the current situation there is no need for additional investment and land resources, the cost of resources and environmental impact make the current system less competitive.

However, the results are influenced by the choice of indicators, which also include subjectivity. More experts could be taken, but even the human factor would remain. In the future analysis, sensitivity analysis of the criteria weights can be used to clarify each criterion weight influences on the results.

\section{ACKNOWLEDGEMENT}

This research is funded by the Ministry of Economics of the Republic of Latvia, project "Development of heat supply and cooling systems in Latvia”, project No. VPP-EM-EE-2018/1-0002.

\section{REFERENCES}

[1] Lund H., Werner S., Wiltshire R. 4th Generation District heating (4GDH) Integration smart thermal grids into future suitable energy systems. Energy 2014:68:1-11. doi:10.1016/j.energy.2014.02.089

[2] Ministry of Environmental Protection and Regional Development. Latvian National Energy and Climate Plan 2020-2030.

[3] Data for district heating [Online]. [Accessed 15.03.2019]. Available: https://www.csb.gov.lv/lv/statistika/db

[4] Data for projects implemented by the EU [Online]. [Accessed 15.03.2019]. Available: www.esfondi.lv

[5] Joelsson J., Gustavsson L. Swedish biomass strategies to reduce $\mathrm{CO}_{2}$ emission and oil use in an EU context. Energy 2012:43(1):448-468. doi:10.1016/j.energy.2012.03.050

[6] Rodzkin A., Kundas S., Charnenak Y., Khroustalev B., Wichtmann W. The Assessment of Cost of Biomass from PostMining Peaty Lands for Pellet Fabrication. Environmental and Climate Technologies 2018:22(1):118-131. $\underline{\text { doi: } 10.2478 / \text { rtuect-2018-0008 }}$ 
[7] Ostergaard P. A., Lund H. A renewable energy system in Frederikshavn using low-temperature geothermal energy for district heating. Applied Energy 2011:88(2):479-487. doi:10.1016/j.apenergy.2010.03.018

[8] Morvaj B., Evins R., Carmeliet J. Decarbonizing the electricity grid: the impact on urban energy systems, distribution grids and district heating potential. Applied Energy 2017:191:125-140. doi:10.1016/j.apenergy.2017.01.058

[9] Mauthner F, Weiss W, Spork-Dür M. Solar heat worldwide. Markets and € contribution to the energy supply 2013. Institute for Sustainable Technologies, 2015.

[10] European solar district heating system database [Online]. [Accessed 15.03.2019]. Available: http:// solar-district-heating.eu/ServicesTools/Plantdatabase.aspx

[11] Asadabadi M. R. The stratified multi-criteria decision-making method. Knowledge-Based Systems 2018:162:115-123. doi:10.1016/j.knosys.2018.07.002

[12] Zaniolo C. Expressing and supporting efficiently greedy algorithms as locally stratified logic programs, 2015. [Online] Available:

http://citeseerx.ist.psu.edu/viewdoc/download;jsessionid=303696FFBF56110B156D1950B9F394B4?doi=10.1.1.699. $5302 \&$ rep=rep $1 \&$ type $=$ pdf

[13] Taha R. A., Daim T. Multi-criteria applications in renewable energy analysis, literature review. Research and technology management in the electricity industry. London: Springer-Verlag, 2013.

[14] Wang J.-J., Jing Y.-Y., Zhang C.-F., Zhao J.-H. Review on multi-criteria decision analysis aid in sustainable energy decision-making. Renewable and Sustainable Energy Reviews 2009:13(9):2263-2278. doi:10.1016/j.rser.2009.06.021

[15] Zihare L., Blumberga L. Market Opportunities for Cellulose Products From Combined Renewable Resources. Environmental and Climate Technologies 2017:19(1):33-38. doi:10.1515/rtuect-2017-0003

[16] Latosov E., Volkova A., Siirde A., Kurnitski J., Thalfeldt M. Methodological Approach to Determining the Effect of Parallel Energy Consumption on District Heating System. Environmental and Climate Technologies 2017:19(1):5-14. doi:10.1515/rtuect-2017-0001

[17] European Union Emissions Trading Scheme 4 [Online]. [Accessed 01.04.2019]. Available: http://www.varam.gov.lv/lat/darbibas_veidi/emisiju_tirdznieciba/emisiju_tirdzniecibu_periodi/?doc=25877 